\title{
Reviewing New and Renewable Energy Applicable to Roads and Estimating Energy Intensity
}

\author{
Guenhee Lee, Jongdae Baek, Hyejung Hu, and Duckyoon Ku
}

\begin{abstract}
This study reviews technologies of new and renewable energy applicable to roads as part of the effort to reduce emissions of carbon dioxide which is causing global warming and to secure sources of alternative energy. It was found that solar light energy and small wind power energy are most appropriate for roads whose main functions focus on vehicle transport. The key for implementing solar light power generators and wind power generators are to secure maximum hours of sunlight and a consistent wind velocity throughout the year, respectively. The study estimated that solar light energy intensity is $578.2 \mathrm{Wh} / \mathrm{m}^{2} / \mathrm{d}$ on an average daily basis and wind power intensity at $5.53 \mathrm{kWh} / \mathrm{d}$ on an average daily basis for $1 \mathrm{~kW}$ wind power generator by considering capability of energy generators for the two renewable energy types and the climate conditions of Korea.
\end{abstract}

Index Terms-Energy intensity, new and renewable energy, solar energy, wind power energy.

\section{INTRODUCTION}

Global warming refers to the rising average temperature of the earth. It rose by $0.74^{\circ} \mathrm{C}$ for last 100 years but it is forecasted to rise by as high as $6.4^{\circ} \mathrm{C}$ compared to the current (2014) temperature at the end of the 21 st century. [1] The Ministry of Environment said the amounts of global economic loss incurred by climate change are $5 \sim 20 \%$ of the global GDP per year [1].

The primary cause of global warming is subsequent emissions of carbon dioxide by excessive use of fossil fuels. It is said that amount of oil, which is the most common fossil fuel, used for one year in the 1950s is being entirely consumed in six weeks today. Economic growth has given convenience to humankind but it is at the expense of a sharp decrease in fossil fuels available to mankind. Industrialization and economic growth around the world are disproportionate to depletion of fossil fuels.

Road is an essential component of nations for economic

Manuscript received September 15, 2014; revised January 5, 2015. This paper is based on the work done under the Carbon Neutral Road Technologies Development project of the 2011 Construction Technology Innovation Program. The authors thank the Korea Agency for Infrastructure Technology Advancement (KAIA) and the Ministry of Land, Infrastructure and Transport (MOLIT) for the research support.

Guenhee Lee, Jongdae Baek, and Hyejung Hu are with the Highway and Transportation Division, Korea Institute of Civil Engineering and Building Technology, 283 Goyangdae-Ro, Gyeonggi 411-712, Republic of Korea (e-mail: ghlee@kict.re.kr, jdbaek@kict.re.kr, hhu@kict.re.kr).

Duckyoon Ku is with the Korea Energy Management Corporation, 388 poeundaero. Suji-gu, Yongin city Gyeonggi-do, Republic of Korea (e-mail: nanach@kemco.or.kr). growth and also one of the most important national infrastructure. However, huge amount of fossil fuels are being consumed and carbon dioxide corresponding to the fuel use are being emitted. Therefore, the effort to reduce carbon dioxide emissions on roads is a mission mankind has to face and achieve.

Countries around the world have been making efforts to reduce energy use and carbon emissions on road. Implementing facilities for generating energy using alternative energy source is one of the efforts. Due to the importance of the issue, Korea government also has been supported lots of researches related to climate change and energy savings. A research project for developing the technologies of 'Carbon-neutral roads (Green road)' is one of the researches, which was begun in Nov. 2011. It includes a research topic for measuring effectiveness of implementing alternative energy generation facilities on roads.

This paper introduced definitions of new and renewable energy in Korea and describes the energy sources of new and renewable energy. Then, capabilities of new and renewable energies applicable to roads were reviewed. Energy intensity of the applicable new/renewable energy to roads were estimated by considering climate conditions of Korea so as to be used for measuring impact of road alternative energy.

\section{THEORETIC OBSERVATION}

\section{A. Definition of New and Renewable Energy}

"New and renewable energy" is a combination of new energy and renewable energy. "New energy" refers to energy that converts the existing fossil fuels or uses electricity or heat through a chemical reaction such as hydrogen and oxygen. Hydrogen energy, fuel cell, liquefied or gasified energy, and energy that gasified heavy residue oil all belong to new energy. "Renewable energy" refers to energy that converts all renewable energy such as sun, water, geothermal heat, rainfall, and microorganism. Solar energy, wind power energy, hydropower energy, geothermal energy and bio energy all belong to renewable energy

\section{B. Types of New and Renewable Energy}

\section{1) Solar energy}

Solar energy is broadly divided into solar light and solar heat energies.

\section{a) Solar light energy}

Solar light energy refers to the energy that uses photoelectric effect to turn sunlight energy into electricity; it is evolved from solar heat generation technology and more eco-friendly and can adjust amount of productions of 
electricity. However, it has disadvantage of high initial cost and high unit cost for generation.

\section{b) Solar heat energy}

Solar heat energy refers to energy using heat emitted from the sun towards earth. Solar heat is used for direct heating by taking high heat or producing electricity through heat exchanger; which boils water and generates electricity using the power of rotating turbines by high-pressure vapor from boiled water.

It is an infinite source of energy as long as sun emits heat. It is free of contamination as it does not emit greenhouse gas. And it can be generated in wider part of the world unlike fossil fuels, which are collected only from limited parts of the world. However, it requires high initial cost but energy efficiency is poor relative to the cost.

\section{2) Wind power energy}

Wind power is one of the key sources of new and renewable energy. It is a natural and an infinite energy that does not emit environmental contaminants such as carbon dioxide and radioactive waste. It is one of the most highlighted sources of new and renewable energy as a solution to address depletion of fossil fuels and environmental challenges caused by global warming.

Wind power generation taps into aerodynamic nature of kinetic energy found in air movement. Wind rotates a rotor and motion energy is converted into mechanical energy and eventually exchanged into electricity. Wind power generators have mostly been built onshore of mountains or seaside. Technological advances have resulted in bigger wind power generators; it produced limitations in installing locations and noise problem. Due to these, the number of offshore wind farms in the coastal regions and fiord were gradually increased.

\section{3) Geothermal energy}

Geothermal energy is defined as energy that land (soil, underground water, and surface water) preserves by magma heat. Temperature difference between water, underground water and underground heat is used for cooling or heating. High-temperature vapor generated from geothermal heat is also used to run turbine and produce electricity. Geothermal system usually refers to the system for the former usage.

According to US Environment Protection Agency, geothermal heat pump system is the most energy-efficient, eco-friendly and cost-effective system among all existing cooling/heating technologies.

\section{4) Fuel cell}

Fuel cell is the device that converts chemical energy created from chemical reaction of hydrogen and oxygen into electric energy. It is basically composed of a cell that is connected with anode, electrolyte layer and cathode. Multiple cells can be stacked to get a voltage and electric current of choice.

When hydrogen gas is supplied to anode, hydrogen is split into hydrogen ion $(\mathrm{H}+)$ and electron (e-) in the anode's catalyst layer. Hydrogen ion moves to cathode via air layer to combine with the oxygen supplied and create water, which is oxygen reduction reaction. In this process, electron's external flow forms electric current to generate electricity and heat.

\section{5) Hydropower energy}

Hydropower generation is a technology that uses flow energy of water. It is well known that hydropower is one of the most reliable and consistent sources of renewable energy available. Hydropower generation system consists of water conveyance, turbine or waterwheel, and alternator or generator, regulator, and wiring. Water conveyance such as channel, pipeline, or pressured pipeline transports water from a dam or a beam to turbine or waterwheel. Alternator or generator transforms rotational energy into electricity. Regulator controls the generator, and wiring delivers the electricity.

\section{6) Ocean energy}

Ocean energy generates electricity or heat with tides, waves, current, and temperature difference of sea.

\section{7) Bio energy}

Bio energy is liquefied, gasified or solidified fuel, electricity, or thermal energy generated through converting biomass directly, biologically, chemically or physically

\section{8) Waste energy}

Waste energy is generated by processing waste into fuel by using appropriate technology, not by simply burning or burying waste generated in daily lives or during industrial activities. The fuel is then used as an alternative to coal, oil or gas fuel. Waste heat from burning is used as the energy.

\section{9) Coal liquefied gas energy}

Coal gasification and liquefaction technology refers to gasifying cheap fuel (coal, waste, heavy residue oil, etc.) with oxygen and steam and refining composite gas (mainly composed of carbon monoxide and hydrogen) to convert it into premium energy such as electricity, chemical materials, liquid fuel and hydrogen.

\section{0) Hydrogen energy}

Hydrogen energy technology takes advantages of separating and generating hydrogen that exists in the form of composites such as water, organic materials and fossil fuels. It does not emit contaminants other than minimum amount of nitrogen when hydrogen is burned. It can be conveniently used as fuel for direct combustion and fuel cell, and can be made from water which is infinite. Also, it can be easily stored and transported in a gas or liquid form. Hydrogen can be easily gained by water electrolysis but economics of hydrogen energy is extremely poor compared to input energy (electric energy). To cope with this, studies are being carried out to develop manufacturing technology using improved catalyst or an alternative power source.

\section{NEW AND RENEWABLE ENERGY APPLICABLE TO ROADS AND CONSIDERATIONS}

\section{A. New and Renewable Energy Applicable to Roads}

Road types can be classified into national freeways, national highways, and provincial roads managed by metropolitan cities, cities, counties and districts. This study limited the road scope to national freeways and national highways. 
New and renewable energy applicable to roads is quite limited since main function of roads is to support vehicle transport. The facility for new and renewable energy requires enough space to install certain size equipment and needs infrastructure system for electricity network, fuel supply, etc.

Given such consideration, it was found that the most appropriate types of new and renewable energy for roads are solar light energy and wind power energy Solar heat and geothermal energy that generate thermal energy may be used for cooling or heating auxiliary buildings (tollgate, buildings for road construction projects, etc.) and hydrogen fuel cell may be used in limited areas that can access city gas.

Therefore, this study investigate the capability of solar light energy and wind power energy Wind power energy, however, is limited to small wind power generation under $10 \mathrm{~kW}$ since big ones cannot be installed road side due to size.

\section{B. Considerations}

Energy load other than direct energy consumption from vehicles and road construction will most likely come from lights and facilities for road operation. Energy for energy consumed for cooling/heating and lighting are required only in certain period of the year and during nighttime respectively. By contrast, energy generation from new and renewable energy facilities is not controllable by us. To address this, energy storage system could be put in place to store surplus energy and used stored energy when generated energy is not enough or use energy from Korea Electric Power Corporation's power (KEPCO) when generated energy is not enough.

However, energy storage system is not an economic choice until now. That is why most of the new and renewable energy facilities on roads should be linked to KEPCP's power system unless energy is used only in a small amount or facilities are located in extremely remote areas.

Therefore, to build new and renewable energy facilities, it is required to be assured whether there are KEPCO's power transmission lines close to the region set or not and the capacity of the lines in early planning stage.

\section{1) Solar light energy}

All solar light generation facilities should be installed by the construction standards for solar light facilities provided by New and Renewable Energy Center at Korea Energy Management Corporation. The facilities should be built in areas that can secure as much sunlight as possible and are away from shade caused by shrubs or structures since sunshine hours is the key to amount of power generation. If solar cell modules are placed in two rows on a flat inclined plane, installer should make sure modules at the back row are not shadowed by ones in the front row.

Anti-weed sheets should be installed or labor activities to root out weeds need to be planned because sites for photovoltaic generators are prone to weeds, which can overshadow solar cell modules in summer and undermine efficiency of power generation. Some countries have released sheep or ostrich to graze weeds.

Inclined planes of road sides or lands close to ICs can be a good place for solar light generation facilities since those are usually idle lands and not easily accessible to humans. Tollgates or rooftops of auxiliary buildings for road management are good locations as well.

\section{2) Wind power energy}

Consistent wind velocity throughout the year should be the first point of consideration when applying wind power generators on roads. Unlike solar light generation facilities, wind power generators will become useless unless there is a minimum amount of velocity needed for operation. Hence, velocity of $3 \sim 4 \mathrm{~m} / \mathrm{s}$, which is the minimum level needed to small wind power generators, should be in the site throughout the year. Applicable land sites for small wind power generators are road slopes and idle land.

Wind generated from driving vehicles can also be used for wind power energy production. Initially, it is formed towards the direction in which a vehicle pushes air to outside but later creates a whirlpool. This can be utilized by setting up a vertical wind power generator on the median to generate electricity. It can be built on front/back of air blast fan inside tunnels, too. Some countries propose an idea to build a structure and a vertical wind power generation plan on the upper side of the road to take advantage of driving wind. But, this can only be applied in regions with consistent vehicle traffic and driving speed.

Lately, there have been studies to generate wind power by harnessing lower bridge structures but they should be accompanied by aerodynamic studies to mitigate whirlpool vibration in bridges. Appropriate application of small wind power generator in the lower bridge structure can be a good element for generating electricity and bridge security.

\section{INTENSITY OF NEW AND RENEWABLE ENERGY APPLICABLE TO ROADS}

\section{A. Solar Light Energy}

\section{1) Average cross-sectional area of crystalline solar cell module}

Solar cell module, which is the major part of solar light generation facilities, can be divided into crystalline solar cell module and thin-film solar cell module. The both are commercially available but crystalline solar cell module is most widely used across the world due to its high efficiency and competitive price. Accordingly, energy intensity in solar light is analyzed based on crystalline solar cell module.

Crystalline solar cell modules are combined based on output of solar cells, they have wide variety of size. Size and capacity distribution of solar cell module should be identified to calculate daily energy production per unit area. Size and capacity distribution of 875 products certified by New and Renewable energy Center at Korea Energy Management Corporation is shown in Fig. 1.

Table I and Fig. 2 show distribution of average capacity $\left(\mathrm{W} / \mathrm{m}^{2}\right)$ per unit size of crystalline solar cell module. Capacity per unit size is growing driven by technological advances in solar cells and commercialization. In consideration of such factors, this study applied $155.43 \mathrm{~W} / \mathrm{m}^{2}$ as average capacity $\left(\mathrm{W} / \mathrm{m}^{2}\right)$ per unit size of crystalline solar cell module, which is the average capacity per unit size of crystalline solar cell module in the last three years. 

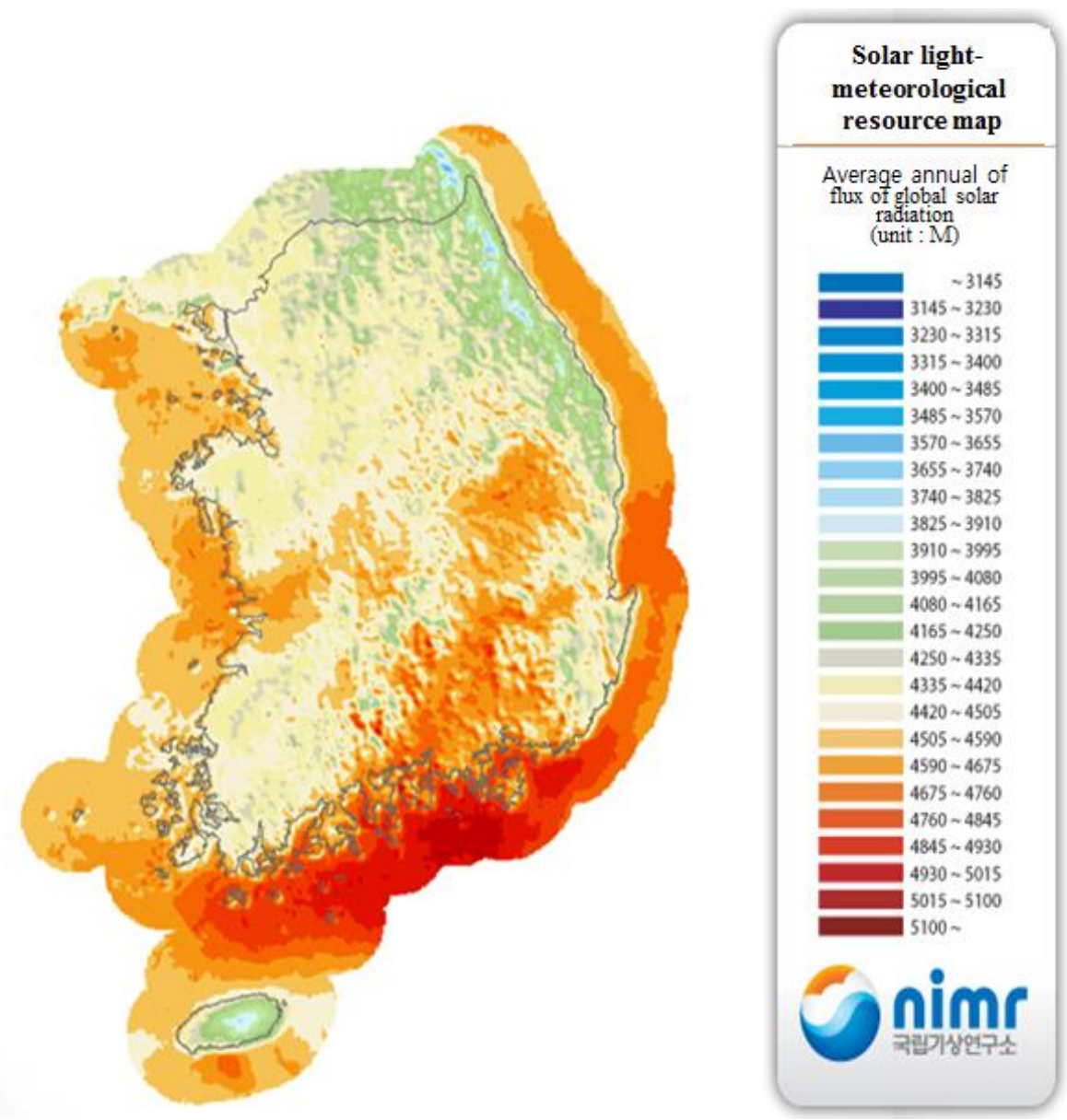

Fig. 1. Capacity and size distribution of crystalline solar cell module.

\section{$\operatorname{Area}\left(m^{2}\right)$}

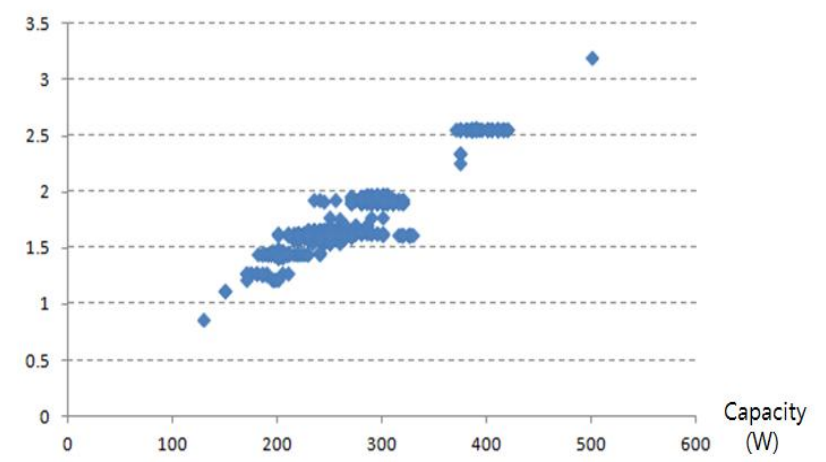

Fig. 2. Capacity $\left(\mathrm{W} / \mathrm{m}^{2}\right)$ trend per average unit size by year.

TABLE I: AVERAGE CAPACITY (W/M²) PER UNIT SIZE OF CRYSTALLINE SOLAR CELL MODULE

\begin{tabular}{llllllllr}
\hline \hline Year & 2008 & $\mathbf{2 0 0 9}$ & $\mathbf{2 0 1 0}$ & $\mathbf{2 0 1 1}$ & $\mathbf{2 0 1 2}$ & $\mathbf{2 0 1 3}$ & $\mathbf{2 0 1 4}$ & $\begin{array}{c}\text { Three-year } \\
\text { average }\end{array}$ \\
\hline $\begin{array}{l}\text { Average } \\
\text { capacity }\end{array}$ & & & & & & & \\
per unit \\
size
\end{tabular}

2) Daily average generation from solar light generation facilities

Solar light generation is largely determined by daily sunlight. Generation starts upon sunrise and peaks are between $12 \mathrm{pm}$ to $1 \mathrm{pm}$ during when sun light is the strongest. Generation stops after sunset. Amount of generation is affected by season and regional characteristics.

Annual average flux of global sunlight based on solar meteorological resource map by National Institute of Meteorological Research is depicted in the Fig. 3. Amount of sunlight is relatively greater in the southern region but this study calculates daily average amount of generation based on nationwide average since it considers applying solar light generation facilities just about in any roads across the country [2].

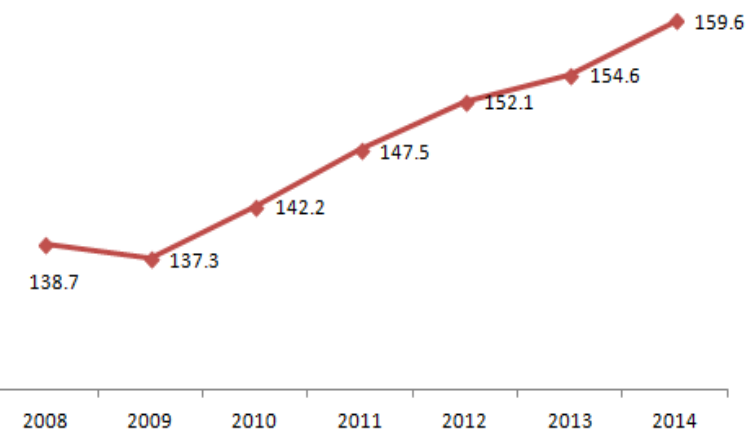

Fig. 3. Solar light-meteorological resource map.

Utilization of solar light generation is calculated using Equation (1). It is required to be known to calculate daily average solar light generation from facilities. The general solar light generation utilization in Korea is $15.5 \%$ [3]

$$
\text { Utilization }=\frac{\text { Amount of generation }[\mathrm{kWh}]}{\text { Facilities capacity }[\mathrm{kW}] \times \text { generationhours }[\mathrm{h}]} \times 100[\%](1)
$$

Daily average amount of solar light generated per unit 
capacity is estimated as follows:

Daily average amount of solar light generation per unit $\operatorname{size}\left(\mathrm{Wh} / \mathrm{m}^{2} \cdot \mathrm{d}\right)$

$=$ acilities capacity per area size $\left(\mathrm{W} / \mathrm{m}^{2}\right) \times 24$ hours $\times$ average utilization

$$
\begin{gathered}
=155.43 \mathrm{~W} / \mathrm{m}^{2} \times 24 \mathrm{~h} \times 15.5 \% \\
=578.2 \mathrm{Wh} / \mathrm{m}^{2} / \mathrm{d}
\end{gathered}
$$

\section{B. Wind Power Energy}

Wind power generators can be distinguished into Vertical Axis Wind Turbine (VAWT) in which rotating axis is vertical to the surface depending on rotating axis' direction of wing and Horizontal Axis Wind Turbine (HAWT) in which rotating axis is horizontal to the surface. VAWT has simple structure and thus easy to install but is more sensitive to wind direction. HAWT, on the other hand, is frequently found in deserts and plains as it is not sensitive to wind direction but its materials are expensive and lags behind HAWT in terms of efficiency.

According to A. Betz, generating power of wind power generators is determined by rotor diameter and wind velocity. Following is the formula. Fig. 4 shows the relationship between diameters and rotation sizes.

$$
\text { Power }=1 / 2 \rho \mathrm{C}_{p} \mathrm{AV}^{3}
$$

$\rho$ : air density $\mathrm{kg} / \mathrm{m}^{3}$

$\mathrm{C}_{p}$ : output coefficient

A: rotor rotation $\operatorname{size}\left(\pi * \mathrm{D}^{2} / 4\right.$, D: rotor diameter $)$

$\mathrm{V}$ : velocity

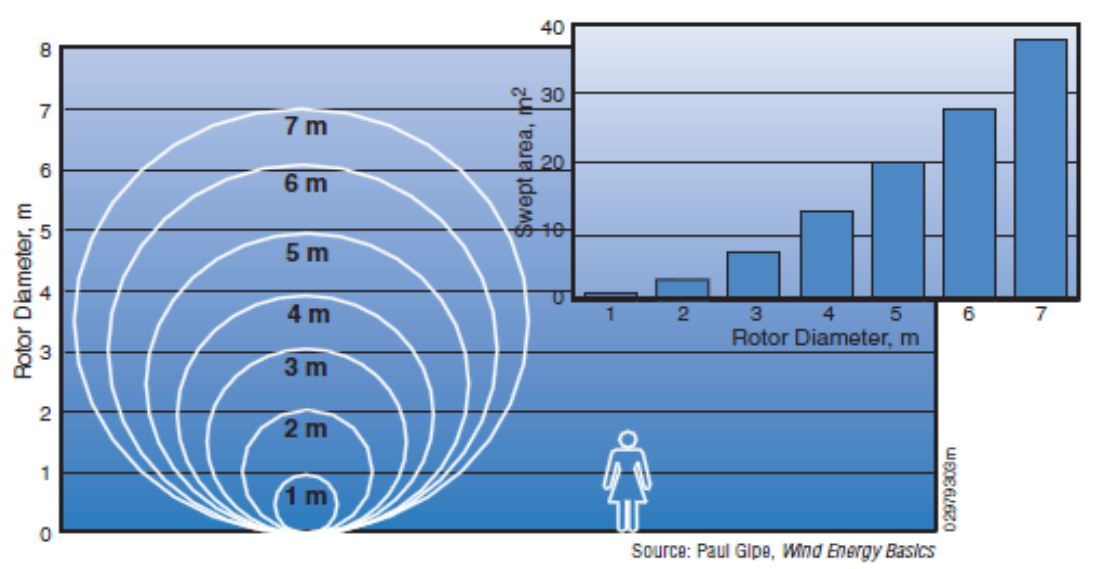

Fig. 4. Diameter and rotation size.

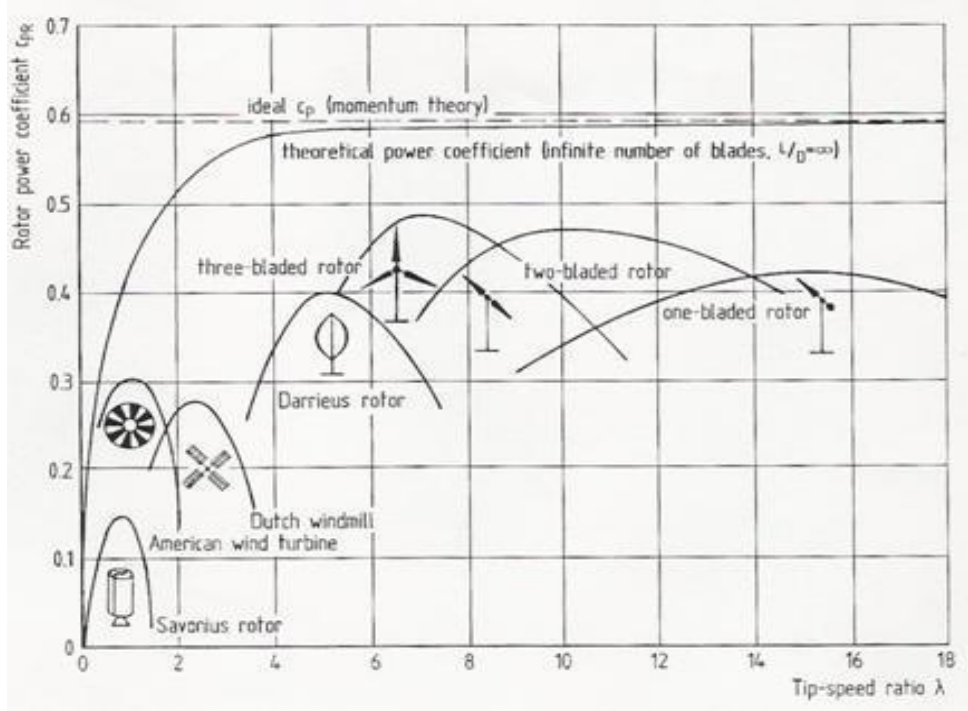

Fig. 5. Output coefficient by type of wind power generator.

According to A. Betz, maximum output coefficient, $\mathrm{C}_{p}$ is 0.593 means that up to $59.3 \%$ of wind's kinetic energy can be converted into electric energy per hour. But, this is only theoretical value. The value will inevitably go down when considering efficiency of rotor and efficiency of mechanical and electric devices in wind power generators. Fig. 5 depicts the output coefficient by type of wind power generator. Among of all generators developed so far, the highest efficiency of three-blade horizontal axis wind turbine is $48 \%$. Among vertical ones, Darius-shaped generator is $40 \%$ efficient. Efficiency of vertical wind power generators is low in general [4].

Velocity data for each region is required to calculate daily average amount of generation in wind power generators. According to wind-meteorological resource map provided by National Institute of Meteorological Research, areas showing over $3 \sim 4 \mathrm{~m} / \mathrm{s}$ in velocity, which is the minimum required for small wind power generators to run, are mostly located in coastal regions as shown in Fig. 6 [5]. 


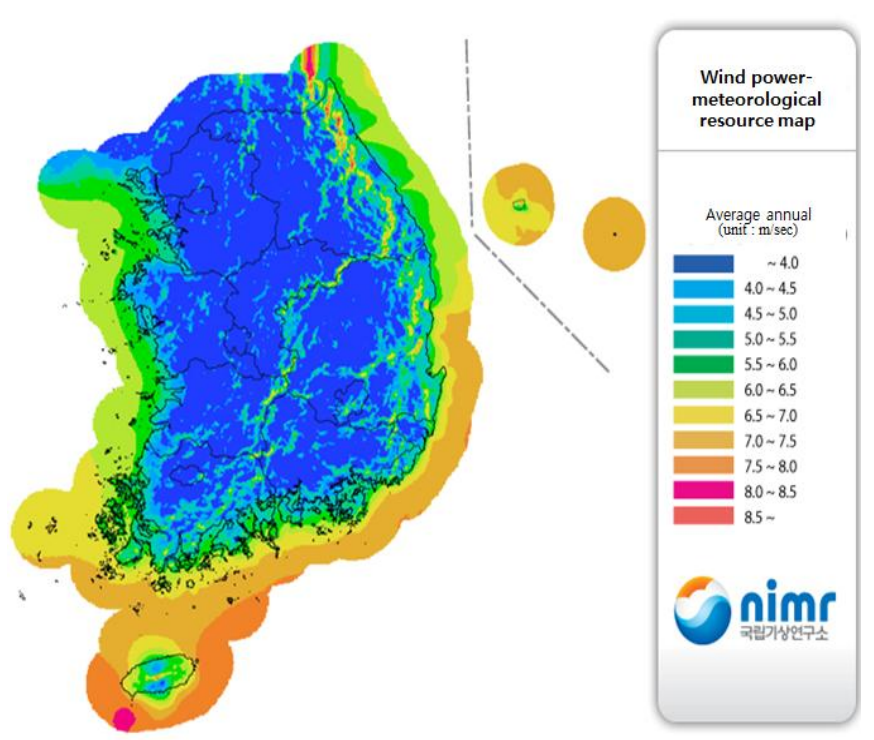

Fig. 6. Wind power-meteorological resource map (average annual).

Wind power-meteorological resource map is produced using observations and forecasted values for the locations of $50 \mathrm{~m}$ aboveground. Therefore, National Institute of Meteorological Research says velocity distribution in $10 \mathrm{~m}$ aboveground in the resource map can be exaggerated than the actual observed values. This should be taken into account for small wind power generators to be installed on roads as they will be installed within $10 \mathrm{~m}$ aboveground.

Amount of wind power generation is determined by diameter of blade and velocity as shown in Betz's formula. Since velocity widely varies by region compared to solar light, all small wind power generators are assumed to be built in areas with appropriate velocity. In addition, assumed conditions and estimated output in the research -by Korea Institute of Civil Engineering and Building Technology [6] were used to calculate daily average amount of wind power generated from one $1 \mathrm{~kW}$-capacity wind power generator.

Annual amount of energy generated is forecasted at 2.02MWh when assuming that a $1 \mathrm{~kW}$-capacity horizontal wind power generator with $3 \mathrm{~m}$ in blade diameter is built in a location $10 \mathrm{~m}$ aboveground with around $4.1 \mathrm{~m} / \mathrm{s}$ in annual average velocity. Based on this value, a daily average amount of wind power generated from each of the $1 \mathrm{~kW}$ wind power generator is forecasted at $5.53 \mathrm{kWh} / \mathrm{d}$.

\section{CONCLUSION}

This study reviewed 10 types of new and renewable energy technologies including solar energy, wind power energy and geothermal energy as part of subprojects laid out by the research group to develop technologies for carbon-neutral roads, which was launched to explore ways to reduce carbon dioxide emissions, secure resources for alternative energy and save energy, thereby tackling global warming. It particularly looked into new and renewable energy applicable to roads. Considering road's main function in vehicle transport, limited infrastructure related to new and renewable energy facilities and limited area to satisfy proper size of new and renewable energy facilities, solar light energy and small wind power energy appear to be most apt for application to roads.

Solar light generators should be built in areas that can secure as much sunlight as possible and are away from shade caused by shrubs or structures since sunshine hours is the key to amount of power generation. Wind power generators should be built in areas with consistent velocity throughout the year. When using vehicles' driving wind, it should be noted that vehicles push air to the outside at first but later create whirlpool.

The study reviewed distributions of size and capacity of solar cell modules certified by New and Renewable Energy Center at Korea Energy Management Corporation in order to determine daily energy generation and solar light energy intensity. Intensity was calculated as $578.2 \mathrm{Wh} / \mathrm{m}^{2} \mathrm{~d}$ based on $15.5 \%$ in utilization of solar light generation in Korea. The study estimated $5.53 \mathrm{kWh} / \mathrm{d}$ for daily average amount of wind power generation per $1 \mathrm{~kW}$ wind power generator by considering velocity resource map by National Institute of Meteorological Research using the Betz's formula.

Calculating quantitative benefits of new and renewable energy facilities on roads in Korea based on the estimated intensity of solar light and wind power energy from this study is expected to have a positive impact on promoting implementation of new and renewable energy facilities on roads in the future.

\section{REFERENCES}

[1] The Ministry of Environment, Korea, Report of international environmental issues and coordination acts, 2014.

[2] Weather Resources Map. Solar light meteorlogical resource map. [Online]. Available: http://www.greenmap.go.kr/

[3] Y. Shin, R. Jung, and J. Ko, Present Situation and Utilization-Rate of a Mass Solar-Powerplant in Korea, The Korean Institute of Electrical Engineers, pp. 469-471, 2008.

[4] E. Hau, Wind Turbines: Fundamentals, Technologies, Application, Economics, Springer, Germany, 2006.

[5] Weather Resources Map. Wind power meteorlogical resource map. [Online]. Available: http://www.greenmap.go.kr/

[6] S. Kwon, S. Lee, and H. Lee, "Aerodynamic performance improvement of bridges via small wind power generators and energy generation," in Proc. IMAC-XXVIII, Korea Society of Civil Engineering, Florida, USA, 2011.

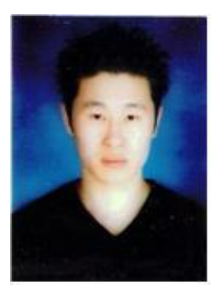

Guenhee Lee is an associate researcher at Korea Institute of Civil Engineering and Building Technology (KICT). He received his bachelor of engineering degree in urban engineering from Daejin University in 2007. He received his master of engineering degree in urban engineering from Hanyang University in 2009. He decided to focus on studying transportation engineering after receiving his master degree and is taking a $\mathrm{Ph} . \mathrm{D}$ degree course at the same university. He is currently involved in various researches on sustainability of roads.

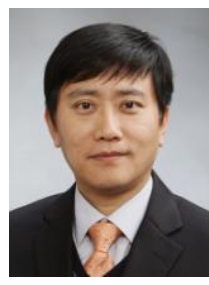

Jongdaeg Baek received his bachelor of engineering degree from the University of Seoul in 1999. He continued his study as a graduate student in the Department of Transportation Engineering at the same university and received his master of engineering degree in 2001. After two years of work experience as a researcher at the Korea Institute of Civil Engineering and Building Technology (KICT), he went to Raleigh, North Carolina to pursue a Ph.D. in civil engineering at North Carolina State University in 2003 and received his Ph.D. degree in 2007. After four years of his work as a post doc at the Highway Safety Research Center at the University of North Carolina, he came back to Korea and has been working at Highway \& Transportation Research Division in KICT as a senior researcher. His areas of experience include road geometry improvement, road safety countermeasure evaluation, and recently sustainable road strategies. 
Hyejung Hu is a senior researcher at Korea Institute of Civil Engineering and Building Technology (KICT). She received her bachelor of engineering degree in urban engineering from Hongik University in 1999. She decided to focus on studying transportation engineering and studied for her master degree at the University of Seoul which is one of the great schools in transportation engineering in Korea. After receiving her master degree in 2001, she worked at the Government of Seoul City for two years. Her duty was improving the Seoul traffic signal operation systems. She went to North Carolina State University in 2003 and earned her Ph.D. degree in 2009. After two years of her post doc period at the Institute for Transportation Research and Education in NCSU, she came back to Korea and began to work at KICT. She is currently involved in various researches on sustainability of transportation.

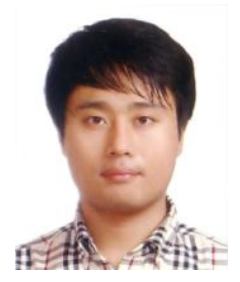

Duckyoon Ku is a manager at Korea Energy Management Corporation, which is a government agency responsible for the implementation of energy conservation policies and energy efficiency improvement measures as well as climate change mitigation activities. He received his bachelor of engineering degree in electronic and electrical engineering from Hongik University in 2005 . 